DOI:10.33099/2311-7249/2020-39-3-107-116

УДК 355.41

Володимир Олександрович Дачковський (кандидат техних наук, доцент)

Національний університет оборони Украӥни імені Івана Черняховського, Київ, Украӥна

\title{
ШЛЯХИ ВИЗНАЧЕННЯ ПОКАЗНИКІВ ЯКОСТІ ОЗБРОЄННЯ ТА ВІЙСЬКОВОÏ ТЕХНІКИ
}

\begin{abstract}
Озброєння та військова техніка є продукиією багатьох підприємств оборонно-промислового комплексу Украӥни, які приймають участь у їх виготовленні та ремонті. Вітчизняні виробники для утримання свого положення на конкурентному ринку мають більше уваги приділяти очінюванню рівня якості продукції, яка випускається і послуг, які надаються, та використовувати результати цієї оцінки у виробничій діяльності при прийнятті управлінських рішень.

Рівень якості зразків озброєння та військової техніки можна оцінити відношенням характеристик якості, побудованих на порівнянні отриманих значень з базовими значеннями відповідних показників.

Тому для оцінювання рівня якості зразків озброєння та військової техніки, які поступають на доукомплектування військових частин (підрозділів) від заводів виробників ремонтно-відновлювальних військових частин (підрозділів) запропоновано методичний підхід щяодо визначення показників якості зразків озброєння та військової техніки.

Як варіант показники якості зразків озброєння та військової техніки класифікуються на групи за відповідними ознаками. Відповідно до мети очінювання рівня якості озброєння та військової техніки розглянуто диферениійний, комплексний, змішаний і статистичний методи оиінювання.

Для ефективного оцінювання рівня якості зразків озброєння та військової техніки необхідно розробити модель управління якістю автоматизованого контролю технологічного процесу виготовлення та ремонту озброєння та військової техніки. Суть якої полягає у застосуванні автоматизованої порівняльної оцінки показників, які закладені в технічній документації з фактичними показниками виробу.
\end{abstract} вироби.

Ключові слова: якість; ремонт, виробництво; озброєння та військова техніка; показники;

\section{Вступ}

Розбудова системи логістики в Збройних Силах (3C) України на усіх рівнях ієрархії (стратегічний, оперативний, тактичний) повинна створити умови щодо своєчасного та безперебійного забезпечення військових частин (підрозділів) необхідними матеріальними засобами у відповідності до визначених класів постачання на відповідних логістичних смугах.

В той же час, однією із функцій системи логістики є своєчасне відновлення пошкоджених зразків озброєння та військової техніки (ОВТ), які отримали бойові пошкодження або вийшли з ладу iз експлуатаційних причин. Від своєчасності повернення у військові частини (підрозділи) відремонтованих зразків ОВТ визначатиметься ступінь їх укомплектованості а відповідно й можливості військових частин (підрозділів) щодо виконання поставленого завдання.

Постановка проблеми. Ефективності функціонування системи відновлення та технічного обслуговування зразків ОВТ в операції Об'єднаних сил (ООС) присвячена значна кількість праць [1-4]. Про те, дані роботи спрямовані на отримання відомостей щодо визначення можливостей ремонтновідновлювальних органів (РВО) 3 відновлення пошкоджених зразків ОВТ на різних рівнях ієрархії, визначенню можливостей РВО 3 технічного обслуговування зразків ОВТ, тощо.
Аналіз функціонування системи відновлення ОВТ свідчить [5], що неодноразово зразки ОВТ після проведення робіт щодо приведення їх до працездатного стану знову повертались у РВО. Усе це свідчить про низьку якість ремонту пошкоджених зразків ОВТ, недотримання вимог технологічного процесу, тощо, що відповідно приводить до додаткових фінансових, трудових витрат на усунення виявлених дефектів на зразках OBT.

Аналіз останніх досліджень і публікацій. Дослідженню питань щодо оцінювання якості виробництва, технічного обслуговування та ремонту ОВТ присвячена ціла низка робіт, як вітчизняних так і закордонних вчених, зокрема в роботі [6] запропоновано підхід до визначення критеріїв для оцінювання продукції авторемонтних заводів, а у публікації [7] проведено дослідження щодо вимог споживачів автосервісу за результатами якого з'ясовано, що перевагу віддають співвідношенню ціни та якості обслуговування. В літературних джерелах [8] висвітлюються проблеми управління якістю технічного обслуговування і ремонту автомобілів 3 напруженим ритмом роботи, а також запропоновано шляхи підвищення ефективності управління якістю технічного обслуговування i ремонту, а [9] присвячена розробленню моделі інформаційного контролю технологічного процесу ремонту. Яка спрямована на забезпеченні якості 
ремонту за рахунок застосування автоматичного аналізу придатності до ремонту вузлів і деталей. Окремі аспекти даної проблематики викладені у роботі [10], яка присвячена оцінюванню рівня якості процесу ремонту обладнання з урахуванням факторів, які впливають на якість ремонту та оцінюванню їх кількісних показників, що забезпечують необхідний рівень ефективності експлуатації, а робота [11] присвячена визначенню міри якості обслуговування в рамках налаштування послуг 3 ремонту автомобілів. Робота [12], присвячена вимірюванню та оцінюванню якості обслуговування та ремонту автомобілів методом експертних оцінок. Опрацювання цієї проблеми розглянуто також у публікації [13] в якій проведено аналіз якості використання послуг аутсорсингом щодо обслуговування та ремонту обладнання та озброєння, а у роботі [14] досліджується якість продукції, яка випускається. Оцінка базується на застосуванні комплексних характеристиках якості. Запропоновано значення індексу якості за критерієм ціни використовувати на всіх етапах виробництва автомобілів. Деякі питання даної проблематики розглянуто у роботі [15], яка присвячена дослідженню факторів, які впливають на якість виконання технологічних операцій під час ремонту двигунів. В літературних джерелах [16] проведено аналіз якості транспортних засобів, які застосовуються на різних стадіях життєвого циклу. Головною якістю даних засобів, визначено "Надійність", а у [17] розглянуто питання щодо забезпечення якості ОВТ на різних етапах життєвого циклу. В роботі [18] розглянуто вимоги стандартів, які забезпечують якість ОВТ, а у роботі [19] запропоновано порядок визначення прогнозованих значень показника якості зразка OBT. В роботі [20] розглядаються методичні підходи до обгрунтування властивостей груп показників якості ОВТ, які закуповують в рамках державного оборонного замовлення воєнною організацією держави.

Мета статті. Тому мета роботи полягає у теоретичному обгрунтуванні показників якості OBT, визначенні шляхів забезпечення якості ремонту ОВТ в РВО на усіх рівнях ієрархії та розробленні практичних рекомендацій щодо використання методів оцінювання рівня якості OBT.

\section{Виклад основного матеріалу дослідження}

Система виробництва та ремонту ОВТ має бити зацікавлене в тому, щоб швидше i краще освоювати та впроваджувати у життя праці вчених i конструкторів. Вирішення цього завдання справа, звичайно, непроста та вимагає переосмислення застарілих звичок.

Інший момент - це рівень вимог, які пред'являють до якості зразків ОВТ, які мають бути найвищими. Тобто, відповідати кращим світовим і вітчизняним вимогам. Цього необхідно домагатися рішуче відкидаючи усе застаріле i впроваджувати нові розробки та технології.

Озброєння та військова техніка $є$ продукцією багатьох підприємств, зайнятих їх виготовленням ремонтом. Тому від якості окремих складових зразків ОВТ буде залежати якість виготовлення зразків ОВТ.

Під якістю продукції та послуг розуміють здатність задовольняти замовників [21-22], тобто це деяка сукупність властивостей зразків ОВТ, які обумовлюють придатність продукції задоволенню певних потреб замовників.

Відповідно властивості продукції виражаються у об'єктивній особливості, які виявляються при їх створенні, експлуатації, застосуванні, тобто продуктивність, трудомісткість виготовлення, маневреність, тощо. Кількісними характеристиками якості ОВТ є показники якості i рівень якості.

Під показником якості ОВТ необхідно розуміти кількісну характеристику однієї або декількох властивостей зразка ОВТ, які складають його якість, відповідно до певних умов його створення і експлуатації або застосування. Однією із таких властивостей може бути ремонтопридатність зразка ОВТ, а показник якості - середній час його відновлення.

Рівень якості зразків ОВТ можна оцінити відношенням характеристик якості зразків ОВТ, побудованих на порівнянні значень показників якості ОВТ, яка оцінюється 3 базовими значеннями відповідних показників.

Технічний рівень ОВТ можна визначити відношенням характеристик якості OBT, побудованих на порівнянні значень показників, які характеризують технічну досконалість зразків ОВТ, яка оцінюється 3 відповідними базовими значеннями.

Як варіант показники якості ОВТ можна класифікувати на групи за такими ознаками [23] (табл. 1).

За метою і сферою застосування зразків ОВТ показники, які характеризують ефект від застосування OBT за призначенням в конкретній ситуації (бойових діях).

За пристосованістю зразків ОВТ до експлуатації і збереженню працездатності можна класифікувати на:

показники живучості та стійкості до зовнішніх впливів. Дані показники характеризують здатність OBТ виконувати свої функції при бойовому пошкодженні або в аварійних ситуаціях а показники стійкості до зовнішніх впливів характеризують здатність ОВТ зберігати працездатність при впливах уражаючих факторів зброї а також природного середовища [24];

показники надійності характеризують здатність зразків ОВТ зберігати значення експлуатаційних показників на певному рівні в заданому інтервалі часу (напрацювання) за певних умов застосування [25];

ергономічні показники характеризують пристосованість зразків ОВТ до експлуатації людиною;

показники технічної естетики характеризують композиційну цілісність, інформаційну виразність, раціональність форми і культуру виробничого виконання ОВТ; 


\begin{tabular}{|c|c|}
\hline технічного & характеризують \\
\hline обслуговування, & ехнічні особливості ОВТ, що \\
\hline характеризують властивості зразків ОВТ, що & обумовлюють безпеку особового склад \\
\hline $\begin{array}{l}\text { обумовлюють потрібні витрати матеріалів, засобів, } \\
\text { праці і часу, а також необхідну кваліфікацію }\end{array}$ & $\begin{array}{l}\text { природного середовища } \text { на } \\
\text { експлуатації ОВТ. }\end{array}$ \\
\hline обслуговуючого персоналу при технічному & показники скритності \\
\hline обслуговуванні, ремонті і зберіганні ОВТ. & характеризують \\
\hline транспортабел & приховування (або помилкової імітації) сво \\
\hline $\begin{array}{l}\text { характеризують пристосованість } \\
\text { переміщення; }\end{array}$ & $\begin{array}{l}\text { дислокації, призначення, складу, структури } \\
\text { параметрів виробів від всіх видів розвіді } \\
\text { ймовірного противника [26]. }\end{array}$ \\
\hline
\end{tabular}

Класифікація показників якості виробництва

\begin{tabular}{|l|l|}
\hline \multicolumn{1}{|c|}{ Класифікація показників } & \multicolumn{1}{c|}{ Групи показників якості ОВТ } \\
\hline За способом вираження & Показники, які виражені у натуральних величинах; \\
& Показники, які виражені у грошових одиницях. \\
\hline За кількістю характерних & Одиничні; \\
властивостей & Комплексні (групові, узагальнені, інтегральні). \\
\hline Які застосовуються для & Базові показники; \\
оцінювання & Показники відновлення; \\
& Прогнозовані показники; \\
& Проектні показники; \\
& Виробничі показники; \\
& Експлуатаційні показники. \\
\hline
\end{tabular}

По раціональності техніко-економічних рішень, які застосовано на зразках ОВТ їх класифікують на:

показники стандартизації і уніфікації, які характеризують рівень стандартизації, внутрішньо-проектної і між-проектної уніфікації зразків ОВТ;

показники технологічності, які обумовлюють оптимізацію витрат матеріалів, засобів, праці i часу при технологічній підготовці виробництва та виготовленні зразка ОВТ;

конструктивні показники характеризують конструктивні особливості ОВТ, що обумовлюють можливість реалізації на зразку ОВТ комплексу його функціональних властивостей;

економічні показники, які характеризують витрати на розробку, виготовлення і експлуатацію OBT, а також ефективність, експлуатації.

Кожен показник якості зразків ОВТ характеризується коефіцієнтом вагомості кількісною характеристикою значущості даного показника якості ОВТ серед інших показників його якості.

Відповідно до мети оцінювання рівня якості OBT розробляються показники якості і методи їх визначення табл. 2.

Таблиця 2

Методи, визначення значень показників якості ОВТ

\begin{tabular}{|l|l|}
\hline \multicolumn{2}{|c|}{ Признаки розподілу методів визначення значень } \\
показників якості праці & \multicolumn{1}{|c|}{ Метод визначення значень показників якості } \\
\hline У відповідності до способу отримання інформації & $\begin{array}{l}\text { Вимірювальний } \\
\text { Реєстраційний } \\
\text { Органолептичний } \\
\text { Розрахунковий }\end{array}$ \\
\hline У відповідності до джерела отримання інформації & Традиційний \\
& Експертний \\
& Соціологічний \\
\hline
\end{tabular}

За базовий показник якості беруть значення показників якості, прийняті за основу при порівняльній оцінці якості зразків ОВТ.

Базовими значеннями показників якості при виробництві ОВТ залежно від мети оцінювання рівня якості повинні виступати:

показники якості найкращих існуючих вітчизняних або зарубіжних аналогів зразків ОВТ, які оцінюються;

показники якості гіпотетичних, тобто не існуючих виробів, показники якості яких повинні відповідати сучасним або перспективним науковотехнічним досягненням;

кількісні вимоги тактико-технічних завдань, технічних умов, стандартів та інших нормативно- технічних документів.

Вибір показників якості при ремонті ОВТ здійснюється залежно від мети оцінювання рівня якості ОВТ. В [23] розглядаються такі показники якості зразків ОВТ: одиничний, комплексний, визначальний, інтегральний, індекс якості ОВТ і індекс дефектності ОВТ.

Як правило за визначальним показником якості OBТ приймають рішення щодо оцінювання якості. Він визначається за формулою

$$
\mathrm{K}_{\mathrm{o}}=\sum_{\mathrm{i}=1}^{\mathrm{n}} \mathrm{d}_{\mathrm{i}} \mathrm{K}_{\mathrm{i}}
$$

де $\mathrm{K}_{\mathrm{i}}$ - одиничний або комплексний показник; 
$\mathrm{d}_{\mathrm{i}}$ - коефіцієнт вагомості $i$-го показника, якості зразків ОВТ;

$\mathrm{n}$ - кількість показників.

Якщо визначальний показник $є$ комплексним, його називають узагальненим.

Якщо при оцінюванні якості зразків ОВТ хоча 6 один одиничний показник дорівнюватиме нулю, то узагальнений показник приймають рівним нулю, тобто якість зразків ОВТ визнається незадовільною [27].

Інтегральний, показник якості зразків ОВТ визначають як відношення сумарного корисного ефекту від експлуатації або застосування зразків OBТ $P$ до сумарних витрат на його створення $\mathrm{S}_{\mathrm{c}}$ і експлуатацію або застосування $\mathrm{S}_{\mathrm{a}}$

$$
\mathrm{I}=\frac{\mathrm{P}}{\mathrm{S}_{\mathrm{c}}+\mathrm{S}_{\mathrm{a}}}
$$

Індекс якості зразків ОВТ $\epsilon$ комплексним показником якості різнорідних виробів (агрегатів, тощо) ОВТ, виготовлених за розглянутий період, він дорівнює середньому зваженому відносних значень показників якості цих виробів (агрегатів, тощо) та визначається за формулою

$$
\mathrm{I}_{\mathrm{pq}}=\sum_{\mathrm{i}-1}^{\mathrm{n}} \mathrm{d}_{\mathrm{i}} \frac{\mathrm{K}_{\mathrm{i}}}{\mathrm{K}_{\mathrm{i} b}}
$$

де $\mathrm{I}_{\mathrm{pq}}$ - індекс якості зразків ОВТ;

$\mathrm{K}_{\mathrm{i}}$ - комплексний показник якості $i$-го виробу (агрегату, тощо);

$\mathrm{K}_{\mathrm{ib}}$ - базове значення показника якості $i$-го виробу (агрегату, тощо);

$\mathrm{d}_{\mathrm{i}}$ - коефіцієнт вагомості показника якості $i$ го виробу (агрегату, тощо).

Відповідно коефіцієнт вагомості визначається за формулою

$$
\mathrm{d}_{\mathrm{i}}=\frac{\mathrm{C}_{\mathrm{i}}}{\sum_{\mathrm{i}=1}^{\mathrm{S}} \mathrm{C}_{\mathrm{i}}}
$$

де $\mathrm{C}_{\mathrm{i}}$ - вартість виробу (агрегату, тощо) $i$-го виду в розглянутий період.;

$\mathrm{S}$ - кількість номенклатури виробів (агрегатів, тощо).

Коефіцієнт дефектності зразків ОВТ визначається як середня зважена кількість дефектів, що припадають на одиницю виробів. Він визначається за формулою

$$
\mathrm{D}=\frac{1}{\mathrm{w}} \sum_{\mathrm{i}=1}^{\mathrm{k}} \mathrm{m}_{\mathrm{i}} \mathrm{r}_{\mathrm{i}}
$$

де w - обсяг вибірки;

k - кількість видів дефектів;

$\mathrm{r}_{\mathrm{i}}$ - коефіцієнт вагомості дефекту $i$-го виду;

$\mathrm{m}_{\mathrm{i}}$ - число дефектів $i$-го виду у вибірці.

Коефіцієнт вагомості кожного виду дефекту може бути визначений експертним методом або за вартістю усунення дефекту даного виду.

Відносний коефіцієнт дефектності Q визначається за формулою

$$
\mathrm{Q}=\frac{\mathrm{D}}{\mathrm{D}_{\mathrm{b}}}
$$

де $\mathrm{D}_{\mathrm{b}}$ - базове значення коефіцієнта дефектності, яке відповідає певному базовому періоду виробництва.

Індекс дефектності зразків ОВТ є комплексним показником якості різнорідних виробів (агрегатів, тощо), виготовлених за розглянутий інтервал часу, рівний середньому зваженому коефіцієнту дефектності цих виробів. Він визначається за формулою

$$
\mathrm{I}_{\mathrm{pd}}=\sum_{\mathrm{i}=1}^{\mathrm{S}} \mathrm{r}_{\mathrm{i}} \mathrm{Q}_{\mathrm{i}}
$$

де $\mathrm{Q}_{\mathrm{i}}$ - відносний коефіцієнт дефектності виробів $i$-го виду.

Вибір методу оцінювання рівня якості зразків OBT в процесі виробництва залежить від мети оцінювання, тобто від характеру рішень, які треба прийняти на основі результатів оцінювання.

Тому для оцінювання рівня якості зразків ОВТ можна застосувати наступні методи: диференційний, комплексний, змішаний, статистичний.

Диференціальний метод полягає в зіставленні одиничних показників якості зразків ОВТ, які оцінюються, з базовими показниками

$$
\mathrm{Q}_{\mathrm{qi}}=\frac{\mathrm{P}_{\mathrm{i}}}{\mathrm{P}_{\mathrm{ib}}} \text { або } \mathrm{Q}_{\mathrm{qi}}^{\prime}=\frac{\mathrm{P}_{\mathrm{ib}}}{\mathrm{P}_{\mathrm{i}}}
$$

де $\mathrm{Q}_{\mathrm{qi}}, \mathrm{Q}_{\mathrm{qi}}^{\prime}$ - відносне значення показника якості;

$\mathrm{P}_{\mathrm{i}}$ - одиничний показник якості зразка ОВТ, який оцінюється;

$\mathrm{P}_{\mathrm{ib}}$ - базове значення показника якості.

3 відносних показників якості $\mathrm{Q}_{\mathrm{qi}}, \mathrm{Q}_{\mathrm{qi}}^{\prime}$ вибирається той, при якому збільшення показника відповідає поліпшенню якості зразка ОВТ, тобто $\mathrm{Q}_{\mathrm{qi}}$ вибирається для продуктивності, надійності, a $\mathrm{Q}_{\mathrm{qp}}^{\prime}$ - для маси, вартості,тощо.

Комплексний метод оцінювання рівня якості зразків ОВТ заснований на використанні комплексних показників, тобто показників які характеризують кілька властивостей зразків ОВТ. Іноді для обгрунтування рекомендацій щодо прийнятих рішень виявляється доцільним охарактеризувати рівень якості одним числом. Комплексна оцінка якості зразків ОВТ є одним 3 питань, які вирішуються кваліметрією.

В основі кваліметрії лежать наступні принципи:

якість зразків ОВТ, які представляють собою сукупність властивостей, i може бути представлено у вигляді багаторівневої ієрархічної структури -“дерева властивостей”, яке будується за визначеними правилами [28] рис. 1.

Кожна властивість на будь-якому рівні має одиничний $\mathrm{P}_{\mathrm{i}}$ або комплексний $\mathrm{K}_{\mathrm{i}}$ a також відносний показник $\mathrm{Q}_{\mathrm{qi} \text { i }}$ якості. 
Information and analytical activities in the field of security and defense

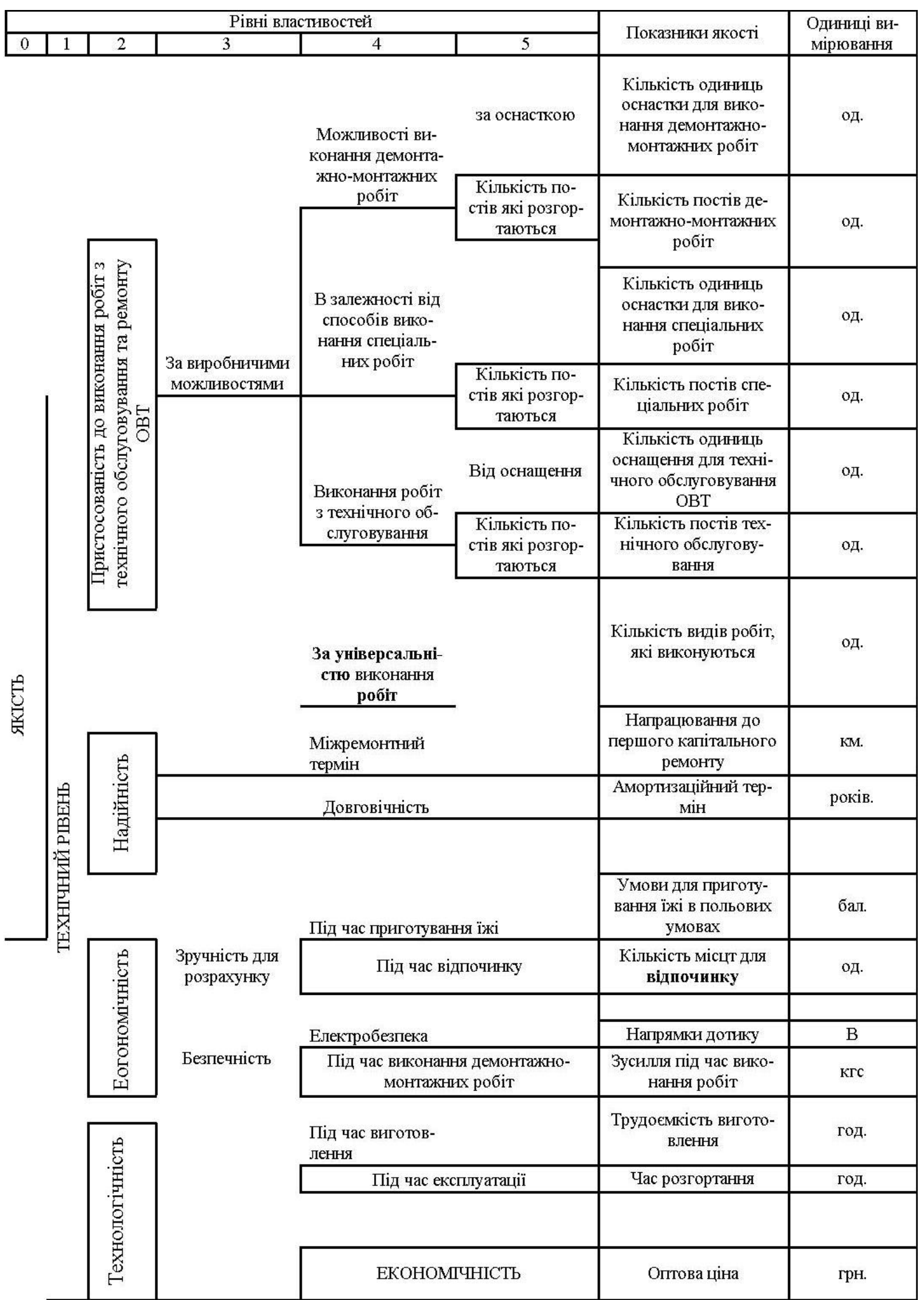

\section{Рис. 1 Дерево властивостей рухомих засобів ремонту}

Кожна властивість характеризується також коефіцієнтом вагомості $\mathrm{d}_{\mathrm{i}}$, що показує значимість, важливість даної властивості в порівнянні 3 іншими властивостями, які знаходяться на одному рівні.

Для всіх властивостей одного рівня

$$
0 \leq \mathrm{d}_{\mathrm{i}} \leq 1 \text { i } \sum_{\mathrm{i}=1}^{\mathrm{n}} \mathrm{d}_{\mathrm{i}}=1
$$

Загальна комплексна оцінка якості зразків ОВТ К $\sum$ визначається як середня зважена арифметична оцінка окремих властивостей

$$
{ }^{\mathrm{K}} \sum=\sum_{\mathrm{i}=1}^{\mathrm{n}} \mathrm{d}_{\mathrm{i}} \mathrm{Q}_{\mathrm{qi} \mathrm{i}}
$$

Оскільки існує умова

$$
0 \leq \mathrm{Q}_{\mathrm{qi}} \leq 1 \text { i } 0 \leq \mathrm{d}_{\mathrm{i}} \leq 1
$$


тоді

$$
0 \leq \mathrm{K} \sum \leq 1
$$

де $\mathrm{K}$ - не може дорівнювати нулю, так як такі зразки ОВТ не будуть виготовлятися.

Алгоритм кваліметричної оцінки рівня якості зразків ОВТ формулюється наступним чином:

I етап побудова дерева властивостей;

II етап визначення одиничних, комплексних i базових показників якості;

III етап визначення коефіцієнта вагомості;

IV етап визначення комплексної оцінки якості зразка ОВТ.

Змішаний метод оцінювання рівня якості заснований на одночасному використанні одиничних і комплексних показників якості коли мета, яка ставиться при оцінюванні якості зразків OBT, не може бути досягнута диференціальним або комплексним методами. Тобто, коли сукупність одиничних показників $€$ досить великою i аналіз значень кожного показника диференціальний метод не дозволяє отримати узагальнюючі висновки; коли комплексний показник недостатньо повно враховує усі істотні властивості зразків ОВТ і не дозволяє отримувати висновки щодо деяких груп цих властивостей.

Рівень якості зразків ОВТ змішаним методом оцінюється наступним чином:

виходячи 3 призначення ОВТ і характеру мети оцінювання, одиничні показники якості об'єднуються в групи i для кожної групи визначають відповідний їй комплексний показник;

на основі комплексних показників оцінюють рівень якості ОВТ диференціальним методом.

Під час ремонту ОВТ у РВО під оцінюванням рівня якості розуміють сукупність властивостей, процесу ремонту від яких залежить відповідність цього процесу i його результатів встановленим вимогам.

Для визначення рівня якості ремонту ОВТ слід застосовувати коефіцієнти дефектності виготовлених деталей у РВО - середнє зважене кількості дефектів, які припадають на одиницю виробів [29].

Коефіцієнт дефектності $\epsilon$ характеристикою середніх витрат, пов'язаних 3 наявністю дефектів, виражених в грошових одиницях або умовних одиницях - балах, що припадають на одиницю виробів.

Коефіцієнт дефектності визначається за формулою

$$
\mathrm{D}^{\mathrm{c}}=\frac{1}{\mathrm{n}} \sum_{\mathrm{i}=1}^{\mathrm{m}} \mathrm{Z}_{\mathrm{i}}^{\mathrm{c}} \mathrm{d}_{\mathrm{i}}
$$

де $\mathrm{m}$ - кількість усіх видів дефектів, які зустрічаються у зразку ОВТ або вибірці;

$\mathrm{d}_{\mathrm{i}}$ - кількість дефектів $i$-го виду;

$\mathrm{Z}_{\mathrm{i}}^{\mathrm{c}}$ - коефіiєнт вагомості $i$-го дефекту, який може виражатися в грошових одиницях при вартісній оцінці або в балах при бальному оцінюванні;

$\mathrm{n}$ - обсяг вибірки для визначення коефіцієнта дефектності (число проконтрольованих одиниць виробів).

При вартісному методі коефіцієнт вагомості дефекту визначається як сума витрат на його усунення

$$
\mathrm{Z}_{\mathrm{i}}^{\mathrm{c}}=\mathrm{V}_{\mathrm{i}}(1+\mathrm{V})+\mathrm{C}_{\mathrm{i}}
$$

де $\mathrm{V}_{\mathrm{i}}$ - заробітна плата працівникам на усунення $i$-го дефекту;

V - непрямі витрати в процентах до заробітної плати працівників;

$\mathrm{C}_{\mathrm{i}}$ - вартість матеріалів $\mathrm{i}$ комплектуючих виробів.

Існують два способи визначення коефіцієнтів вагомості дефектів - вартісний і бальний.

При бальному методі експерти групують усі дефекти на групи в залежності від їх значимості. Тобто, розрізняють критичні, значні і малозначні дефекти.

До критичних дефектів відносять ті, які можуть призвести до виникнення небезпечних умов для людей, які обслуговують або мають відношення до даного агрегату, або дефект, який може перешкодити виконанню функцій готового зразка OBT.

Значний дефект може привести до аварії або значно зменшити придатність зразка OBT до виконання відповідних функцій.

А малозначний дефект не спричиняє істотного зменшення придатності зразка ОВТ для наміченої мети або ж $\epsilon$ відхиленням від встановлених стандартів, та має незначний вплив на ефективне використання або експлуатацію зразка ОВТ [30].

Дефектам $\mathrm{d}_{\mathrm{i}}$ кожної групи присвоюється певна кількість балів $Z_{i}$ тобто чим значніший дефект, тим більша кількість балів.

Коефіцієнт дефектності $\mathrm{D}^{\mathrm{b}}$ при бальному способі визначається за формулою

$$
\mathrm{D}^{\mathrm{b}}=\frac{1}{\mathrm{n}} \sum_{\mathrm{j}=1}^{\mathrm{r}} \mathrm{Z}_{\mathrm{j}}^{\mathrm{b}} \mathrm{d}_{\mathrm{i}}
$$

де $\mathrm{Z}_{\mathrm{j}}^{\mathrm{b}}$ - коефіцієнт вагомості дефекту в балах;

$\mathrm{d}_{\mathrm{i}}$ - кількість всіх виявлених дефектів $i$-ї групи в $n$ проконтрольованих одиницях ОВТ;

$\mathrm{n}$ - обсяг вибірки для визначення коефіцієнта дефектності (число проконтрольованих одиниць OBT);

$\mathrm{r}$ - число груп дефектів, яке встановлене експертами $\mathrm{j}=1$...r

Бальний спосіб визначення коефіцієнтів вагомості дефектів простіше, але він менш повно і об'єктивно відображає якість виготовлення виробів. Цей спосіб застосовується у виняткових випадках, коли неможливе застосування вартісного способу.

При відомих $\mathrm{D}^{\mathrm{c}}$ i $\mathrm{D}^{\mathrm{b}}$ рівень якості виготовлення виробів визначається за формулою

$$
\mathrm{X}=1-\frac{\mathrm{D}^{\mathrm{c}}}{\mathrm{c}} \text { або } \mathrm{Y}=1-\frac{\mathrm{D}^{\mathrm{b}}}{\mathrm{D}^{*}}
$$

де $\mathrm{D}^{\mathrm{c}}-$ коефіцієнт дефектності виробів (агрегатів, тощо), визначений на основі вартісного 112 ISSN 2311-7249 (Print)/ISSN 2410-7336 (Online) Сучасні інббормахійні технологї̈ у сбері безпеки та оборони № 3 (39)/2020 
методу визначення коефіцієнтів у вагомості дефектів;

$\mathrm{D}^{\mathrm{b}} \quad$ - коефіцієнт дефектності виробів (агрегатів, тощо), визначений на основі бального способу визначення коефіцієнтів вагомості дефектів;

D - максимально можливе значення $\mathrm{D}^{\mathrm{b}}$ для даного виду виробів (агрегатів, тощо);

с - повна планова собівартість одиниці виробів (агрегатів, тощо);

Відповідно максимально можливе значення

$\mathrm{D}^{\mathrm{b}}$ для даних виробів (агрегатів, тощо) можна визначити за формулою

$$
\mathrm{D}^{*}=\mathrm{Z}^{*} \mathrm{~d}^{*}
$$

де $Z^{*}$ - максимальне значення коефіцієнта вагомості дефекту в балах, яке призначається найбільш серйозному дефекту;

d - максимально можлива кількість найбільш серйозних дефектів.

3 формул для $\mathrm{X}$ i $\mathrm{Y}$ випливає, що при відсутності дефектів $\mathrm{X}=1$, а при гранично низькій якості виготовлення виробів (агрегатів, тощо) $\mathrm{X}=0$

Звідси випливає, що призначення максимального числа балів має грунтуватися на нерівності

$$
\mathrm{Zd} \geq \mathrm{Z}_{1} \mathrm{~d}_{1}+\ldots+\mathrm{Z}_{\mathrm{z}-1} \mathrm{~d}_{\mathrm{z}-1}
$$

де $\mathrm{d}_{\mathrm{j}}(\mathrm{j}=1 \ldots \mathrm{r}-1) \quad$ г гранично допустиме нормативно-технічною документацією число дефектів $j$-ї групи.

Зазвичай критичні дефекти не допускаються, тобто $\mathrm{d}=0$. Оскільки в цьому випадку нерівність не має сенсу для призначення $\mathrm{Z}$ при критичних дефектах умовно приймається $\mathrm{d}=1$. Крім вищевикладеного методу оцінювання, оцінку рівня якості ремонту ОВТ за кількістю зважених дефектів можна проводити 3 використанням статистичних даних за попередній період. Ці дані аналізуються і на їх підставі виводяться середні значення, які характеризують рівень якості ремонту ОВТ і виготовлення виробів (агрегатів, тощо). Отримані середні значення використовуються для оцінювання тільки в тому випадку, якщо вони відображають необхідний рівень якості даних виробів. Цей метод використовується при оцінюванні рівня якості ремонту ОВТ, оскільки багаторічний досвід експлуатації відремонтованих зразків ОВТ підтверджує, що якість ремонту в основному задовольняє замовника.

Оцінювання рівня якості ремонту ОВТ на ремонтному підприємстві проводиться 3 метою вирішення наступних завдань:

комплексної оцінки стану виробництва для визначення в кількісному вираженні організаційно-технічного рівня підприємства 3 урахуванням відповідних номенклатурних показників;

виявлення слабких місць підприємства і його підрозділів, які ускладнюють виконання основних завдань підприємства, впровадження нової технології тощо, для розроблення системи управління як на рівні самого підприємства, так і вищестоящих організацій;

комплексного оцінювання змін організаційнотехнічного рівня підприємства в міру впливу системи управління як по окремих показниках, так і за сукупністю.

Показники, які характеризують фактори ремонтного виробництва, обираються на основі статистичних даних за попередні роки таким чином, що їх максимальні значення, повинні бути рівні одиниці, відповідати виконанню в РВО певних вимог до стану виробничого процесу ремонту та виготовлення виробів (агрегатів, тощо) $[21,22,31,32]$. Для кожної вимоги показника, за яким проводиться оцінювання рівня якості, визначаються коефіцієнти зниження.

Для узагальненої оцінки рівня якості ремонту і виготовлення виробів (агрегатів, тощо) в РВО використовується комплексний показник рівня якості $\mathrm{P}_{\mathrm{ql}}$. Він визначається шляхом ділення суми числових значень номенклатурних показників $\mathrm{P}_{\mathrm{n}}$ на число цих показників - $n$

$$
\mathrm{P}_{\mathrm{ql}}=\frac{\sum_{\mathrm{i}=1}^{\mathrm{n}} \mathrm{P}_{\mathrm{n}}}{\mathrm{n}}
$$

Числове значення номенклатурного показника $\mathrm{P}_{\mathrm{n}}$ за винятком $\mathrm{P}_{\mathrm{n} \text { II }}, \mathrm{P}_{\mathrm{n} \text { III }} \mathrm{P}_{\mathrm{n}}$ в визначається за формулою

$$
\mathrm{P}_{\mathrm{n}}=1-\sum_{\mathrm{i}=1}^{\mathrm{n}} \mathrm{K}
$$

де $\mathrm{K}$ - числове значення коефіцієнта зниження невиконаної вимоги показника рівня якості;

$\mathrm{n}$ - кількість невиконаних вимог.

Показник $\mathrm{P}_{\mathrm{n} \text { II }}$, який характеризує якість збирання зразка ОВТ який ремонтується, визначається за формулою

$$
\mathrm{P}_{\mathrm{n} \text { II }}=\frac{\mathrm{K}_{0}}{\mathrm{~K}_{\mathrm{b}}}
$$

де $\mathrm{K}_{\mathrm{b}}$ - базовий показник - кількість перевірених позицій, вказаних в паспорті складання зразка OBT;

$\mathrm{K}_{0}$ - кількість перевірених позицій, які не мають зауважень (одиничний показник).

Показник $\mathrm{P}_{\mathrm{n} \text { III }}$, що характеризує якість випробувань зразків ОВТ оцінюється також як $\mathrm{P}_{\mathrm{n} \text { II }}$.

Показник $\mathrm{P}_{\mathrm{n}} \mathrm{X}$, що характеризує ритмічність ремонту ОВТ, визначається, як частка від ділення фактичного коефіцієнта ритмічності випуску за місяць, $\mathrm{K}_{\mathrm{z}}$, на базовий показник $\mathrm{K}_{\mathrm{b}}=1$.

Фактичний коефіцієнт ритмічності $\mathrm{K}_{\mathrm{X}}$ за місяць визначається за результатами щоквартальної здачі виробів (агрегатів, тощо) як сума трьох найменших квартальних планових i 
фактичних показників випуску виробів (агрегатів, тощо) у відсотках, розділена на 100.

\section{Висновки й перспективи подальших досліджень}

Таким чином, підвищення ефективності застосування зразків ОВТ за призначенням може бути досягнуто тільки від якісного виготовлення виробів (агрегатів, тощо) та якісного проведення ремонтно-відновлювальних робіт в PBO на усіх рівнях ієрархії. Виробники виробів (агрегатів, тощо) мають більше приділяти уваги оцінюванню рівня якості виробів, а РВО рівню якості виконання ремонтно-відновлювальних робіт.

\section{Лimepamypa}

1. Букоємський С. Застосування окремих теоретичних положень у побудові комбінованої адаптивної системи технічного обслуговування і ремонту. Збірник наукових прачь Національної академії Державної Прикордонної Служби Украӥни серія: військові та технічні науки. 2018. № 3(77), с. 191-198. 2. Гулясв А.В., Зубарєв О.В.,КаніщевВ.В., КолодяжнийВ.Б. Підвищення ефективності функціонування системи технічного обслуговування та ремонту озброєння та військової техніки. Озброєння та військова техніка. 2016. №2(10). с. 43-48. 3. Дачковський В.О. Методика оцінювання ефективності функціонування системи відновлення озброєння та військової техніки / В.О. Дачковський, B.I. Коцюруба // науковий журнал "Сучасні інформаційні технології у сфері безпеки та оборони”, НУОУ. - 2020. - № 1(37) C. 5 - 14. DOI: https://doi.org/10.33099/2311-7249/2020-38-2-87-94

4. Поляков А.П., Миронюк М.Ю. Методика визначення періодичності проведення та переліку робіт з технічного обслуговування автомобілів при переведенні їх на експлуатацію за технічним станом. URL:: https://conferences.vntu.edu.ua/index.php/all-fmt/all-fmt2016/paper/viewFile/1298/ 857

5. Копашинський С.А. Аналіз виконання завдань 3 відновлення ОВТ силами та засобами ремонтновідновлювальних військових частин (підрозділів) в ході проведення операції Об'єднаних сил (антитерористичної операціï). Проблеми застосування ремонтновідновлювальних частин (підрозділів) в операціях (бойових діях), кафедра Тх3, І3В(c)IT, НУОУ науковопрактичний семінар 11 лютого 2020 тези. доп. - Київ, 2020 - C. 10-12. 6. Тогизбаева Б.Б., Каражанов А.А., Алипбаев Ж.Р., Кокаев У.Ш. Оценочные критерии качества технического обслуживания и ремонта автомобилей. URL: http://www.rusnauka.com/4_NIC 2016 /Tecnic/4_207135.doc.htm 7. Ложачевська О.М. Григоренко Р.В. Узагальнена класифікація послуг сучасного автосервісу. Вчені записки ТНУ імені B. I. Вернадського. Серія: Економіка і управління. 1018. Том 29 (68). № 2. с. 31-36. 8. Бабич А.П., Пічугін І.М. Шляхи підвищення якості технічного обслуговування і ремонту автобусів на підприємствах автомобільного транспорту України. Збірник наукових праць Харківського університету Повітряних Сил. 201 5, Вип. 1(42). с. 8690. 9. Борзилов І.Д. Забезпечення якості ремонту вагонів в умовах реформування галузі. Збірник наукових праџь УкрДАЗТ, 2013.Вип. 139. с. 87-94. 10. Кузовик В.Д., Кошева Л.О., Кучеренко В.Л. Методика оцінювання рівня якості процесу ремонту медичного обладнання. Системи обробки інформаиіï. 2011.Вип. 6 (96). c. 64-67. 11. Ernest Emeka Izogo Customers' service quality perception in automotive repair, African Journal of Economic and Management Studies, Vol. 6 Iss 3 p. $272-$ 288 Permanent link to this document: http://dx.doi.org/10.1108/AJEMS-02-2013-0024. 12. Lotko M. Measuring and assessment of the quality of motor car maintenance and repair services with using the SERVQUAL
В подальшому стоїть необхідність розглянути систему управління якістю на державному та галузевому рівнях. Та систему управління якістю на заводах, які виготовляють вироби (агрегати, тощо). Також необхідно розробити модель управління якістю автоматизованого контролю технологічного процесу виготовлення та ремонту OBT [33]. Яка спрямована на забезпеченні якості ремонту та виготовлення виробів (агрегатів, тощо) за рахунок застосування автоматизованої порівняльної оцінки показників які закладені в технічній документації з фактичними показниками виробу.

model with regard to customer's profile. The Archives of Automotive Engineering - Archiwum Motoryzacji. 2017. no. 77(3). p. 51-62, http://dx.doi.org/10.14669/AM. VOL.77.ART4 13. Nikolay Stefanov Analysis of the use of outsourcing services for maintenance and repair of the equipment and armament available in the structures of the Bulgarian armed forces. International Conference Knowledge-Based Organization. Vol. XXIII. No 1. 2017. p. 467-472. DOI:10.1515/kbo-2017-0077 14. H. Amineh, N. Kosach Assessment of Consumers' Satisfaction with the Automotive Product Quality. International Journal of Environmental \& Science Education. 2016. Vol. 11, No. 16. p. 8726-8739. 15. Дашивець Г.I., Паніна В.В., Дослідження факторів, що впливають на якість ремонту двигунів. Науковий вісник ТДАТУ. 2014. Вип. 4, Том 1. с. 101-106. 16. Максимов С.Е. Лялинов А.Н., Бондаренко А.Н. Надежность транспортных и технологических машин: формирование и реализация. Современные проблемы науки и образования. 2012. № 3. Електронний pecypc. [Режим доступу] https://www.scienceeducation.ru/ru/article/view? id=6324 17. Маянский В.Д. Обеспечение качества продукции оборонного значения на различных этапах еe жизненного цикла. Менеджмент Вооружение Качество. 2017. №4(54). Електронний ресурс [Режим доступу] https://www. sds vr.ru /assets/docs/MVK/2017/4_1.pdf 18. Критенко М. Обеспечение качества военной продукции новое поколение нормативных документов. Электроника: Наука, Технология, Бизнес. 2000. №4. с. 50-53. 19. Королюк Н.О., Лістровий С.М., Щербаков М.І. Підхід щодо прогнозування показників якості перспективних зразків озброєнь в умовах нестохастичної невизначеності. Сучасні інформаційні технології у сфері безпеки та оборони. 2019. №1 (34). с. 139-142. 20. Смуров А.М. Методические подходы к идентификации показателей качественных и функциональных характеристик продукции, поставляемой по государственному заказу в интересах военной организации государства. Електронний ресурс. [Режим доступу] https://openbooks.itmo.ru/ru/file/4202 /4202.pdf 21. ДСТУ ISO 9000: 2015 Системи управління якістю. Основні положення та словник термінів. - К.: ДП “УкрНДНЦ”, 2016. - 45 с. 22. ДСТУ ISO 9001: 2015 Системи управління якістю. Вимоги. (ISO 9001:2015 IDT). К.: ДП “УкрНДНЦ”, 2016. - 21 с. 23. Мацько О.Й., Терещенко А.М., Копашинський С.А., Овчаренко І.В., Дачковський В.О., Яльницький О.Д., Опенько П.В., Ярошенко О.В., Момот Р.А., Гринчак О.В. Основи організації експлуатації та ремонту озброєння $і$ військової техніки, Київ, НУОУ ім. Івана Черняховського, 2018, 400 с. 24. Dachkovskyi, V.O. Method of determination of survival characteristics of weapons and military equipment. Social development \& Security. - 2020. - №10(1), 18 - 24. 25. ДСТУ 2860-94 Надійність техніки. Терміни та визначення.- К.: Держстандарт України, $1994 . \quad$ - 92 с. DOI: doi.org/10.33445/sds.2020.10.1.3 26. V. Dachkovskyi 
Methodology of justification of tactical and technical requirements for movable means of repairing arms and military equipment. Social development \& Security. № 9(6), 86-101. doi: http://doi.org/10.33445/sds.2019.9.6.7 27. Бондаренко С.М., Леус А.Ю., Оцінка рівня якості продукції на підприємстві. Ефективна економіка. 2017. № 4. Електронний ресурс. [Режим доступу] http://www.economy.nayka.com. ua/?op=1\&z=5527 28 Юрков Б.Н. Исследование операций. - М.: ВИА, 1990. - 528 с. 29. Фещенко В.Н. Обеспечение качества продукции в машиностроении: ученик /В.Н.Фещенко В.Н. - М.: Инфра-Инженерия, 2019. - 788 с. 30. Глухов B.B., Гасюк Д.П., Управление качеством: ученик для вузов. 2-е узд. Стандарт третього поколения. - СПб.: Питер, 2015. - 384 с. 31. Мацько О.Й., Терещенко А.М.,
Копашинський С.А., Смірнов В.О., Дачковський В.О., Прилипа О.О. Основні положення воєнно-технічноі політики держави. Київ, НУОУ ім. Івана Черняховського, 2019. - 352 с. 32. ГОСТ В 15.307 - 77 Система разработки постановки на производство военной техники. Испытания и приемка серийных изделий. Основные положения. - М.: ИПК Издательство стандартов, 1979. - 39 с. 33. Пат. 135424 Україна, МПК (2009) ) F41 Н 7/00. Спосіб перевірки корпусів бойових броньованих машин / Дачковський В.О., Даценко І.П., Коцюруба В.І., Шишанов М.О., Мірненко В.І., Самарай В.П., Бобров Д.С. - заявник і володар патенту Дачковський В.О., Даценко І.П. - № u2019 01311; заяв. 11.02.2019; опуб̆л. 25.06.2019; Бюл. № $12 / 2019$.

\title{
ПУТИ ОПРЕДЕЛЕНИЯ ПОКАЗАТЕЛЕЙ КАЧЕСТВА ВООРУЖЕНИЯ И ВОЕННОЙ ТЕХНИКИ
}

\section{Владимир Александрович Дачковский (кандидат технических наук, доцент)}

\section{Национальный университет обороны Украины имени Ивана Черняховского, Киев, Украина}

Вооружение $и$ военная техника является продукцией многих предприятий обороннопромыиленного комплекса Украины принимающих участие в их изготовлении и ремонте. Отечественные производители для удержания своего положения на конкурентном рынке должны больше внимания уделять оценке уровня качества выпускаемой продукиии и предоставляемых услуг, и использовать результаты этой оценки в производственной деятельности при принятии управленческих решений.

Уровень качества образиов вооружения и военной техники можно оченить отномением характеристик качества, построенных на сравнении полученных значений с базовыми значениями соответствуюших показателей.

Поэтому для оценки уровня качества образцов вооружения и военной техники, поступающих на доукомплектование воинских частей (подразделений) от заводов производителей ремонтновосстановительных воинских частей (подразделений) предложен методический подход по определению показателей качества образиов вооружения и военной техники.

Как вариант показатели качества образиов вооружения и военной техники классифицируются на группь по соответствующим признакам. В целях оченки уровня качества вооружения и военной техники рассмотрено дифференциальный, комплексный, смешанный и статистический методы оценки.

Для эффективного оценивания уровня качества образиов вооружения и военной техники необходимо разработать модель управления качеством автоматизированного контроля технологического прочесса изготовления и ремонта вооружения и военной техники. Суть, которой заключается в применении автоматизированной сравнительной оценки показателей, которые заложены в технической документации с фактическими показателями изделия.

Ключевые слова: качество; ремонт; производство; вооружение и военная техника; показатели; изделия.

\section{WAYS OF DETERMINING QUALITY INDICATORS WEAPONS AND MILITARY EQUIPMENT}

\author{
Volodymyr Dachkovskyi (Candidate of Technical Sciences, Associate Professor)
}

\section{National Defence University of Ukraine named after Ivan Cherniakhovskyi, Kyiv, Ukraine}

Arms and military equipment are the products of many enterprises of the defense-industrial complex of Ukraine, which take part in their manufacture and repair. Domestic producers to maintain their position in a competitive market need to pay more attention to assessing the level of quality of products and services provided, and use the results of this assessment in production activities in management decisions.

The level of quality of samples of armaments and military equipment can be assessed by the ratio of quality characteristics based on the comparison of the obtained values with the base values of the relevant indicators.

Therefore, to assess the level of quality of samples of weapons and military equipment received for the replenishment of military units (units) from factories of manufacturers of repair and restoration units (units) proposed a methodological approach to determining the quality of samples of weapons and military equipment.

As an option, the quality indicators of samples of armaments and military equipment are classified into groups according to the relevant characteristics. In accordance with the purpose of assessing the level of quality of armaments and military equipment, differential, complex, mixed and statistical assessment methods are considered.

To effectively assess the level of quality of samples of armaments and military equipment, it is necessary to develop a model of quality management of automated control of the technological process of manufacturing and repair of armaments and military equipment. The essence of which is to use an automated comparative M odern I nformation Technologies in the Sphere of Security and D efence №2(38)/2020 ISSN 2311-7249 (Print)/ISSN 2410-7336 (Online) 115 
assessment of indicators that are laid down in the technical documentation with the actual performance of the product.

Keywords: quality; repair; production; armament and military equipment; indicators; products.

\section{References}

1. Bukoemsky S. Application of certain theoretical provisions in the construction of a combined adaptive system of maintenance and repair. Collection of scientific works of the National Academy of the State Border Guard Service of Ukraine series: military and technical sciences. 2018. № 3 (77), p. 191-198. 2. Gulyaev, A.V. Zubarev, O.V. Kanishchev, V.V. Kolodyazhny, V.B. Improving the efficiency of the system of maintenance and repair of weapons and military equipment. Weapons and military equipment. 2016. №2 (10). p. 43-48. 3. Dachkovskyi, V.O. Kotsyuruba, V.I. Methods for evaluating the effectiveness of the functioning of the system of weapons and military equipment. Modern Information Technologies in the Sphere of Security and Defence, NUDU. - 2020. - № 1 (37) P. 5-14. DOI: 10.33099 / 2311-7249 / 2020-37-1-5-14 4. Polyakov, A.P. Mironyuk, M.Yu. Methods for determining the frequency of the list of works on maintenance of cars during their transfer to operation according to the technical condition. [Electronic resource]: Access mode: https://conferences.vntu.edu.ua/index.php/all-fmt/all-fmt2016/paper/viewFile/1298/ 857 5. Kopashinskyi S.A. Analysis of the implementation of tasks on the restoration of weapons and ammunition by the forces and means of repair and rehabilitation of military units (units) during the operation of the Joint Forces (anti-terrorist operation). Problems of application of repair and restoration units (subdivisions) in operations (combat operations), Department of ThR, IZV (c) IT, NGO scientific-practical seminar February 11, 2020 thesis. ext. - Kyiv, 2020 - P. 10 12. 6. Togizbaeva, B.B. Karazhanov, A.A. Alipbaev, Zh.R. Kokaev, U.Sh. Evaluation criteria for the quality of maintenance and repair of cars. Electronic resource: [Access mode] http://www.rusnauka.com/4_NIC_ _2016 /Tecnic/4_207135.doc.htm 7. Lozhachevska, O.M. Grigorenko, R.V. Generalized classification of modern car service. Scientific notes of TNU named after VI Vernadsky. Series: Economics and Management. 1018. Volume 29 (68). № 2. p. 31-36. 8. Babich, A.P. Pichugin, I.M. Ways to improve the quality of maintenance and repair of buses at road transport enterprises of Ukraine. Collection of scientific works of Kharkiv University of the Air Force. 201 5, Vip. 1 (42). p. 86-90. 9. Borzilov, I.D. Ensuring the quality of car repairs in terms of industry reform. Collection of scientific works UkrDAZT, 2013. Issue. 139. p. 87-94. 10. Kuzovik, V.D. Kosheva, L.O., Kucherenko, V.L. Methods for assessing the level of quality of the process of repairing medical equipment. Information processing systems. 2011.Vip. 6 (96). p. 64-67. 11. Ernest Emeka Izogo Customers 'service quality perception in automotive repair, African Journal of Economic and Management Studies, Vol. 6 Iss 3 p. 272-288 Permanent link to this document: http://dx.doi.org/10.1108/AJEMS-02-2013-0024. 12. Lotko M. Measuring and assessment of the quality of motor car maintenance and repair services with using the SERVQUAL model with regard to customer's profile. The Archives of Automotive Engineering - Archiwum Motoryzacji. 2017. no. 77(3). p. 51-62, http://dx.doi.org/10.14669/AM. VOL.77.ART4 13. Nikolay Stefanov Analysis of the use of outsourcing services for maintenance and repair of the equipment and armament available in the structures of the Bulgarian armed forces. International Conference Knowledge-Based Organization. Vol. XXIII. No 1. 2017. p. 467-472. DOI: $10.1515 / \mathrm{kbo}-2017-0077$ 14. H. Amineh, N. Kosach, Assessment of Consumers' Satisfaction with the Automotive Product Quality. International Journal of Environmental \& Science Education. 2016. Vol. 11, No. 16. p. 8726-8739. 15. Dashivets, G.I. Panina, V.V. Doslidzhennya factors, which add to the quality of repair of engines. Scientific bulletin of TDATU. 2014. Vip. 4, Vol. 1. p. 101-106. 16. Maksimov. S.E. Lyalinov A.N. Bondarenko A.N. Reliability of transport and technological machines: formation and implementation. Modern problems of science and education. 2012. No. 3. Electronic resource. [Access Mode] https://www.science-education.ru/ru/article/view? $\mathrm{id}=6324$ 17. Mayansky, V.D. Ensuring the quality of defense products at various stages of their life cycle. Management Armament Quality. 2017. No. 4 (54). Electronic resource [Access mode] https://www. sds -vr.ru /assets/docs/MVK/2017/4_1.pdf. 18. Kritenko, M. Ensuring the quality of military products a new generation of regulatory documents. Electronics: Science, Technology, Business. 2000. No. 4. p. 50-53. 19. Korolyuk, N.O. Listrovy, S.M. Shcherbakov, M.I. From the start of predicting the indicators of the quality of promising images of the minds of non-stochastic non-value. Modern information technologies in the sphere of security and defense. 2019. No. 1 (34). p. 139-142. 20. Smurov, A.M. Methodological approaches to the identification of indicators of quality and functional characteristics of products supplied by government orders in the interests of the military organization of the state. Electronic resource. [Access mode] https://openbooks.itmo.ru/ru/file/4202 14202.pdf 21. DSTU ISO 9000: 2015 Yakistyu control system. The main provisions of that vocabulary of terms. - K $\therefore$ DP "UkrNDNTS", 2016. - 45 p. 22. DSTU ISO 9001: 2015 Yakistyu management system. Vimogi. (ISO 9001: 2015 IDT). K .: DP "UkrNDNTS", 2016. - 21 p. 23. Matsko, O.Y. Tereshchenko, A.M. Kopashinsky, S.A. Ovcharenko, I.V. Dachkovskyi, V.O. Yalnitsky, O.D. Openko, P.V. Yaroshenko, O.V., Momot, R.A. Grinchak, O.V. Fundamentals of the organization of exploitation and repair of the plant and equipment, Kiev, NUOU im. Ivana Chernyakhovsky, 2018, 400 p. 24. Dachkovskyi, V.O. Method of determination of survival characteristics of weapons and military equipment. Social development \& Security. - 2020. - №10(1), 18 - 24. 25. DSTU 2860-94 The reliability of technology. Terms and conditions. - K.: Derzhstandart Ukrainy, 1994 - 92 c. DOI: doi.org/10.33445/sds.2020.10.1.3 26. V. Dachkovskyi Methodology of justification of tactical and technical requirements for movable means of repairing arms and military equipment. Social development \& Security. № 9(6), 86-101. doi: http://doi.org/10.33445/sds.2019.9.6.7 27. Bondarenko, S.M. Leus, A.Yu. Estimation of the level of quality of products at the enterprise. The economy is effective. 2017. No. 4. Electronic resource. [Access Mode] http://www.economy.nayka.com. ua $/ ?$ op $=1 \& \mathrm{z}=5527$ 28. Yurkov, B.N. Operations research. - M .: VIA, 1990 .-528 p. 29. Feshchenko, V.N. Product quality assurance in mechanical engineering: student - M.: Infra-Engineering, 2019 .- 788 p. 30. Glukhov, V.V. Gasyuk, D.P. Quality management: student for universities. 2-nd bridle Third generation standard. - SPb $\therefore$ Peter, 2015.- 384 p. 31. Matsko O.Y., Tereshchenko, A.M. Kopashinsky, S.A. Smirnov, V.O. Dachkovskyi, V.O. Prilipa, O.O. The main provisions of the military-technical policy of the state. Kiev, NUOU im. Ivana Chernyakhovsky, 2019. - 352 p. 32. GOST B 15.307 - 77 Development system for launching the production of military equipment. Testing and acceptance of serial products. Basic provisions. - M .: IPK Publishing house of standards, 1979. - 39 p. 33. Pat. 135424 Ukraine, IPC (2009)) F41 H 7/00. Methods of converting the corps of armored fighting vehicles / Dachkovskyi V.O., Datsenko I.P., Kotsyuruba V.I., Shishanov M.O., Mirnenko V.I., Samarai V.P., Bobrov D.S. - applicant and volodar to the patent Dachkovsky V.O., Datsenko I.P. - No. u2019 01311; application 02/11/2019; publ. 06/25/2019; Bul. No. 12/2019. 